\title{
Hubungan Antara Frekuensi Menyikat Gigi, Cara Menyikat Gigi dan Kebiasaan Makan dengan Kejadian Karies
}

\author{
Windi Winarto Putri ${ }^{1}$, Nina ${ }^{2}$ \\ 1,2Program Studi Kesehatan Masyarakat Sekolah Tinggi Ilmu Kesehatan Indonesia Maju \\ Jln. Harapan Nomor 50, Lenteng Agung - Jakarta Selatan 12610 \\ Email : ${ }^{1}$ windiiwinartoputri@gmail.com; ${ }^{2}$ naninna62@gmail.com
}

\begin{tabular}{l}
\hline \\
Editor: - \\
Hak Cipta: \\
C2021 Artikel ini memiliki akses \\
terbuka dan dapat didistribusikan \\
berdasarkan ketentuan Lisensi \\
Atribusi Creative Commons, yang \\
memungkinkan penggunaan, \\
distribusi, dan reproduksi yang tidak \\
dibatasi dalam media apa pun, \\
asalkan nama penulis dan sumber asli \\
disertakan. Karya ini dilisensikan di \\
bawah Lisensi Creative Commons \\
Attribution Share Alike 4.0 \\
Internasional.
\end{tabular}

\section{A B S T R A C T}

Introduction: Dental caries are experienced by all circles of the community, ranging from adults, adolescent age groups, to children of both men and women. Children between 6-12 years of age are more prone to dental diseases such as caries often consume fast food or sweet snacks, at that age there is a change in tooth growth from the oldest tooth into adult or permanent teeth.

Objectives: This research aims to know the relationship between the frequency of teeth brushing, how to brush teeth and eating habits with the incidence of Karies in elementary school students in the work Area Health District Kemang Bogor Year 2019

Method: The design of this research is descriptive analytic to learn the causal relationship between the two variables in a situation or a group of subjects conducted to see the relationship between one variable and the other the approach used In this research is cross sectional. The population of this study is the primary school students of MI Al Islamiyah, MI Al Fitriyah, SDN Pabuaran 01, SDN Bojong 02 with a population of 151 students. Determination of the sample using Slovin method with sample sampling using simple random sampling, obtained as much as 110 respondents. Data retrieval using questionnaires, then processed and analyzed univariate and bivariate.

Result: The results of the analysis showed that there is a relationship frequency tooth brushing ( $p$-value $=0.000)$, How to brush teeth $(P$-value $=0.000)$, and eating habits $(p$-value $=0,000)$ with Genesis Karies on elementary School students in the work area Puskesmas Kemang Bogor District Year 2019. The child will emulate the behavior of his parents, so the parents are expected to know how to brush good teeth and correct

Conclution: The child will emulate the behavior of his parents, so the parents are expected to know how to brush good teeth and correct

Keyword: : Brushing teeth, Caries, Eating habit, Frequency 


\section{Pendahuluan}

Kesehatan gigi dan mulut adalah salah satu bagian dari kesejahteraan umum manusia yang dapat meningkatkan kualitas hidupnya, apabila kesehatan gigi dan mulut tidak dipelihara dengan baik maka akan menyebabkan rasa sakit dan tak nyaman hingga dapat mengganggu aktivitas sehari-hari sehingga seseorang tersebut tidak dapat dikatakan sehat secara sempurna Di dalam mulut manusia mengandung sekitar 750 spesies bakteri, namun masih terdapat 50 spesies bakteri yang ada diantaranya belum teridentifikasi dan beberapa diantaranya terlibat dalam kejadian penyakit mulut sebagai bagian tubuh yang langsung bersinggungan dengan makanan dan minuman yang masuk ke dalam tubuh. ${ }^{1}$ Kesehatan gigi dan mulut yang tidak dijaga dengan baik dapat menimbulkan penyakit, seperti karies gigi, maloklusi dan penyakit periodontal. ${ }^{2}$

Karies gigi adalah hasil interaksi yang terjadi antara bakteri di permukaan gigi, plak atau biofilm, dan karbohidrat yang setelahnya difermentasikan oleh bakteri menjadi suatu asam sehingga terjadilah demineralisasi jaringan keras gigi dan dalam proses ini memerlukan waktu yang lama. Perubahan yang terjadi pada pola makan dapat mengakibatkan meningkatnya prevalensi kejadian karies gigi. ${ }^{3}$ Karies gigi salah satu penyakit yang terjadi di jaringan keras gigi yang disebabkan oleh aktifitas jasad renik dalam karbohidrat yang diragikan. ${ }^{4}$

Berdasarkan data dari Departemen Kesehatan, Kebiasaan menggosok gigi juga menjadi bagian terpenting, berdasarkan data waktu menyikat gigi menunjukan bahwa perilaku masyarakat Indonesia dalam menjaga kesehatan mulut masih sangat rendah. Hal ini ditunjukan oleh data bahwa 91,1\% penduduk Indonesia sudah menyikat gigi, namun hanya 7,3\% yang berperilaku benar dalam menyikat gigi. ${ }^{5}$

Menurut laporan dari Pusat Data dan Informasi menjelaskan bahwa Indeks DMF-T adalah gambaran mengenai tingkat kerusakan gigi dimana nilai didapatkan dari penjumlahan dari indeks D-T, M-T, dan F-T yang menunjukan banyaknya gigi rusak yang dialami seseorang baik berupa Decay atau D, Missing atau Dilihat dari data per daerah di Indonesia, tingkat produktivitas tertinggi pada tahun 2013 ada di Provinsi DKI Jakarta sebesar Rp 102,2 juta per tenaga kerja per tahun, diikuti oleh Provinsi Kalimantan Timur sebesar Rp 76 juta per tenaga kerja per tahun ${ }^{2}$. Sedangkan produktivitas tenaga kerja yang paling rendah terdapat pada Provinsi Nusa Tenggara Timur hanya sebesar Rp 7 juta per tenaga kerja per tahun, diikuti oleh Provinsi Gorontalo sebesar Rp 7,9 juta per tenaga kerja per tahun $\mathrm{M}$ dan Filling atau F (gigi ditumpat). Menurut WHO tahun 2016 kejadian karies gigi diseluruh dunia memiliki angka yang terbilang tinggi yaitu 60-90\% pada anak dibawah usia 18 tahun. Anak usia 6 sampai 12 tahun senang mengkonsumsi makanan cepat saji atau jajanan yang kurang terjaga kebersihannya, terbukti pada angka kejadian karies gigi yang cukup tinggi yaitu mencapai $76,62 \%$. Target yang ditetapkan oleh WHO adalah $90 \%$ anak umur 5 tahun bebas karies. Sedangkan angka kejadian karies gigi di Indonesia pada tahun 2007 mencapai 43,4\% dan meningkat pada tahun 2013 menjadi 53,2\% ${ }^{6}$.

Berdasarkan hasil dari Riset Kesehatan Dasar (Riskesdas) tahun 2018, Mencatat bahwa proporsi masalah gigi dan mulut sebesar $57,6 \%$ angka ini mengalami peningkatan dari tahun sebelumnya yaitu hanya sebesar $53,2 \%$. Secara umum terdapat 45 penyakit gigi dan mulut yang terjadi di Indonesia, salah satunya adalah karies gigi. Hasil tersebut menunjukkan prevalensi $88,8 \%$ mengalami karies gigi dan provinsi Jawa Barat mencapai angka 70,4\%. ${ }^{7}$

Menurut Menteri Kesehatan, kesehatan gigi salah satu yang dapat mendukung percepatan tujuan Millenium Development Goals (MDGs). Dalam meningkatkan MDGs upaya yang dilakukan adalah dengan diadakannya upaya promotif dan preventif untuk masyarakat melalui Usaha Kesehatan Gigi Masyarakat (UKGM) dan Usaha Kesehatan Gigi Sekolah (UKGS). Kesehatan Gigi Sekolah 
(UKGS) adalah program yang dicanangkan oleh Pemerintah dan harus dilaksanakan serta dianggarkan oleh Pemerintah Daerah pada setiap daerah dan sudah berjalan sejak tahun 1951. Usaha Kesehatan Gigi Sekolah adalah salah satu upaya kesehatan yang sangat relevan dalam pelaksanaan pencegahan penyakit gigi dan mulut. Program tersebut ditujukan untuk memelihara, meningkatkan kesehatan gigi dan mulut seluruh peserta didik di sekolah yang membutuhkan perawatan kesehatan gigi dan mulut. ${ }^{8}$

UPT Puskesmas Kecamatan Kemang, Kabupaten Bogor merupakan bagian dari wilayah provinsi Jawa Barat yang termasuk kedalam 14 provinsi di Indonesia dengan masalah kesehatan gigi dan mulut yang memiliki nilai diatas angka nasional yaitu sebesar $28,1 \%$ dan terjadi pada murid dibeberapa Sekolah Dasar diwilayah UPT Puskesmas Kecamatan Kemang Kabupaten Bogor. Berdasarkan hasil pendataan murid kelas 1-6 tahun ajaran 2018-2019 diwilayah Puskesmas Kemang dengan total murid Sekolah Dasar berjumlah 2.221 siswa dengan jumlah 1.007 siswa Laki-laki dan 1.214 siswa Perempuan. Total Sekolah Dasar diwilayah Puskesmas Kemang sebanyak 55 sekolah. Menurut hasil survei penjaringan kesehatan gigi ditahun 2017 mencapai angka 75\% yang menderita karies di Kecamatan Kemang dan menurun ditahun berikutnya menjadi $70 \%$ siswa yang masih mengalami karies gigi dan terkategori tinggi untuk kasus kesehatan gigi dan mulut yang buruk dan ditemuinya masalah yang terjadi dalam pelaksanaan kegiatan UKGS yaitu rendahnya kesadaran orang tua untuk menindak lanjuti proses rujukan yang diarahkan petugas puskesmas untuk membawa anakanaknya ke dokter gigi guna penanganan lebih lanjut dan seringnya melakukan kebiasaan yang salah saat menyikat gigi yaitu hanya dilakukan saat mandi pagi dan sore hari sehingga tidak membantu menurunkan angka kejadian karies di Kecamatan Kemang ini. ${ }^{9}$

Masalah yang dialami oleh pihak puskesmas adalah kurangnya perhatian dari orang tua terhadap kesehatan gigi dan mulut anaknya. Surat rujukan yang diberikan oleh pihak puskesmas tidak ditindak lanjuti oleh pihak orang tua sehingga dibiarkan saja anak yang mengalami karies gigi. Karena orang tua menganggap hal yang biasa selama belum mengalami sakit gigi.

Oleh karena itu, peneliti tertarik untuk melakukan penelitian ditempat Sekolah Dasar yang berada dalam wilayah kerja UPT Puskesmas Kecamatan Kemang ini dengan harapan dapat mendata siswa-siswi yang memiliki faktor resiko tinggi mengalami karies gigi mampu mencegah peningkatan dan menurunkan angka kejadian karies serta Mengetahui Hubungan Kebiasaan Makan dengan Kejadian Karies Pada Murid Sekolah Dasar di Wilayah Kerja Puskesmas Kecamatan Kemang Bogor Tahun 2019.

\section{Metode}

Desain penelitian yang digunakan dalam penelitian ini adalah cross sectional. artinya proses pengumpulan dan pengukuran data variabel bebas dan variabel terikat dilakukan 1 (satu) kali yang bertujuan untuk mempelajari dinamika korelasi antara variabel bebas dan variabel terikat. ${ }^{10}$ Penelitian ini menggunakan teknik probability sampling, yaitu stratified sampling. Metode penelitian ini menggunakan uji chi-square dengan sampel sebanyak 110 responden.

Penelitian ini di Wilayah Kerja Puskesmas Kecamatan Kemang Bogor pada bulan Desember 2019. Tujuan penelitian ini adalah untuk Hubungan Kebiasaan Makan dengan Kejadian Karies Pada Murid Sekolah Dasar di Wilayah Kerja Puskesmas Kecamatan Kemang Bogor Tahun 2019.

Penelitian ini telah berhasil lolos uji etik (etical clearance) yang disah kan oleh komisi etik Sekolah Tinggi Ilmu Kesehatan Indonesia Maju (STIKIM) dengan nomor surat etik 3816/Sket/KaDept/RE/STIKIM/XI/2019. 


\section{Journal of

Hasil

Tabel 1. Distribusi Frekuensi Menyikat Gigi, Cara Menyikat Gigi dan Kebiasaan Makan dengan Kejadian Karies

\begin{tabular}{ccc}
\hline Variabel & Frekuensi & Persentase (\%) \\
\hline Karies Gigi & 24 & 21,8 \\
Tidak ada Karies gigi & 86 & 78,2 \\
Ada Karies gigi & & \\
Frekuensi Menyikat Gigi & 83 & 75,5 \\
Kurang Baik & 27 & 24,5 \\
$\quad$ Baik & & 72,7 \\
Cara Menyikat Gigi & 80 & 27,3 \\
Kurang Baik & 30 & \\
$\quad$ Baik & & 72,7 \\
Kebiasaan Makan $\quad$ & 80 & 27,3 \\
Kurang Baik & 30 &
\end{tabular}

Berdasarkan hasil penelitian pada tabel 1 pada variabel Karies Gigi diketahui bahwa frekuensi terbesar yaitu responden yang ada karies gigi dengan 86 responden $(78,2 \%)$ dibandingkan dengan responden yang tidak ada karies.

Berdasarkan hasil penelitian pada tabel 1 pada variabel Frekuensi Menyikat Gigi diketahui bahwa frekuensi terbesar yaitu responden yang frekuensi menyikat giginya kurang baik dengan 83 responden (75,5\%) dibandingkan dengan responden frekuensi menyikat giginya baik.

Berdasarkan hasil penelitian pada tabel 1 pada variabel Cara Menyikat Gigi diketahui bahwa frekuensi terbesar yaitu responden yang cara menyikat giginya kurang baik dengan 80 responden $(72,7 \%)$ dibandingkan dengan responden cara menyikat giginya baik

Berdasarkan hasil penelitian pada tabel 1 pada variabel Kebiasaan Makan diketahui bahwa frekuensi terbesar yaitu responden yang kebiasaan makannya kurang baik dengan 80 responden $(72,7 \%)$ dibandingkan dengan responden kebiasaan makannya baik.

Tabel 2. Hubungan Antara Frekuensi Menyikat Gigi, Cara Menyikat Gigi dan Kebiasaan Makan dengan Kejadian Karies

\begin{tabular}{|c|c|c|c|c|c|c|c|c|}
\hline \multirow{4}{*}{ Variabel } & \multirow{2}{*}{\multicolumn{4}{|c|}{ Karies Gigi }} & \multirow{2}{*}{\multicolumn{2}{|c|}{ Total }} & \multirow{4}{*}{$\begin{array}{c}\text { Nilai } P \\
\text { Value }\end{array}$} & \multirow{4}{*}{ OR } \\
\hline & & & & & & & & \\
\hline & \multicolumn{2}{|c|}{ Ada Karies Gigi } & \multicolumn{2}{|c|}{$\begin{array}{c}\text { Tidak Ada } \\
\text { Karies Gigi }\end{array}$} & \multirow[t]{2}{*}{$\mathbf{N}$} & \multirow{2}{*}{$\%$} & & \\
\hline & $\mathbf{n}$ & $\%$ & $\mathbf{n}$ & $\%$ & & & & \\
\hline \multicolumn{9}{|c|}{ Frekuensi Menyikat Gigi } \\
\hline Kurang Baik & 73 & 88,0 & 10 & 12,0 & 83 & 100 & \multirow[t]{2}{*}{0,000} & \multirow[t]{2}{*}{7.862} \\
\hline Baik & 13 & 78,2 & 14 & 21,8 & 27 & 100 & & \\
\hline \multicolumn{9}{|c|}{ Cara Menyikat Gigi } \\
\hline Kurang Baik & 71 & 88,0 & 9 & 11.3 & 80 & 100 & \multirow[t]{2}{*}{0,000} & \multirow[t]{2}{*}{7.862} \\
\hline Baik & 15 & 50,0 & 15 & 50,0 & 30 & 100 & & \\
\hline
\end{tabular}

Kebiasaan Makan 


\begin{tabular}{lcccccccc} 
Kurang Baik & 62 & 93,0 & 4 & 6,1 & 66 & 100 & 0,000 & 7.862 \\
Baik & 24 & 54,5 & 20 & 45,5 & 44 & 100 & & \\
\hline
\end{tabular}

\section{Pembahasan}

\section{Frekuensi menyikat gigi dengan Kejadian karies gigi di Puskesmas Kemang Bogor Tahun 2019}

Berdasarkan hasil uji chi square, terdapat hubungan antara frekuensi menyikat gigi dengan kejadian karies gigi. Hubungan ini memiliki nilai $\mathrm{p}$-value $=0,000$ berarti $<0,05$ sehingga berdasarkan uji statistic kedua variable tersebut berhubungan. Responden yang frekuensi menyikat giginya kurang baik berpeluang berpeluang 7,862 atau 8 kali untuk mengalami karies gigi dibandingkan dengan responden yang frekuensi menyikat giginya baik. Pada frekuensi menyikat gigi, rata-rata menyikat gigi pada pagi hari dan sore hari ketika mandi. Namun terdapat juga sampel yang menyikat gigi pada pagi hari ketika mandi dan malam hari sebelum tidur. Sedangkan sampel yang menyikat gigi kurang dari 2 kali sehari, hanya menyikat gigi pada pagi hari atau sore hari ketika mandi.

Penelitian ini sejalan dengan penelitian yang dilakukan oleh Jumriani, 2018 tentang hubungan frekuensi menyikat gigi dengan kejadian karies pada siswa SD Inpres Kota Samarinda menunjukkan diperoleh nilai $\mathrm{p}=0,017<0,05$ yang artinya bahwa ada hubungan antara frekuensi menyikat gigi dengan kejadian karies11. Penelitian ini juga sesuai dengan hasil penelitian Aprinta (2018) tentang Hubungan frekuensi menyikat gigi dan konsumsi makanan kariogenik dengan kejadian karies gigi molar pertama permanen pada anak Sekolah Dasar usia 8-12 tahun Di Desa Pertima, Karangasem, Bali dengan hasil $\mathrm{p}=0,001<0,05$ yang artinya variabel frekuensi menyikat gigi berhubungan dengan kejadian karies gigi. ${ }^{12}$

Frekuensi dapat diartikan sebagai jumlah putaran ulang per peristiwa dalam satuan waktu yang diberikan, sementara frekuensi membersihkan gigi dan mulut merupakan bentuk perilaku yang akan mempengaruhi baik atau buruknya kebersihan gigi dan mulut salah satunya dengan menyikat gigi dengan frekuensi 1 kali, 2 kali, 3 kali hingga 4 kali namun frekuensi menyeikat gigi yang baik adalah minimal 2-3 kali sehari. ${ }^{13}$

\section{Cara Menyikat Gigi dengan kejadian Karies Gigi di Puskesmas Kemang Bogor Tahun 2019}

Berdasarkan hasil uji chi square, terdapat hubungan antara cara menyikat gigi dengan kejadian karies gigi. Hubungan ini memiliki nilai $p$-value $=0,000$ berarti $<0,05$ sehingga berdasarkan uji statistic kedua variable tersebut berhubungan. Responden yang cara menyikat giginya kurang baik berpeluang 7,889 atau 8 kali untuk mengalami karies gigi dibandingkan dengan responden yang cara menyikat giginya baik.

Berdasarkan Penelitian yang dilakukan oleh Sari Siti Salamah, 2017 tentang hubungan antara cara menggosok gigi terhadap kejadian karies gigi pada anak usia sekolah menyatakan bahwa adanya hubungan cara menggosok gigi dengan kejadian karies gigi. Menunjukkan diperoleh nilai $p=0,005<$ 0,05 yang artinya bahwa ada hubungan antara cara menyikat gigi dengan kejadian karies gigi. ${ }^{14}$ Penelitian ini juga sesuai dengan hasil penelitian Sunarti (2018) tentang Hubungan cara menyikat gigi dan jenis makanan yang dikonsumsi dengan kejadian karies gigi dengan hasil $p=0,005<0,05$ yang artinya variabel cara menyikat gigi berhubungan dengan kejadian karies gigi. ${ }^{15}$

Cara menyikat gigi yang baik yaitu dengan gerakan yang pendek dan lembut sertadengan tekanan yang ringan, pusatkan pada daerah yang terdapat plak, yaitu di tepi gusi, permukaan kunyah gigi dimana terdapat fissure atau celah-celah yang sangat kecil dan sikat gigi yang paling belakang ${ }^{16}$. 


\section{Journal of

Menurut peneliti cara menyikat gigi adalah suatu teknik atau cara membersihkan seluruh bagian gigi dengan berbagai gerakan. Karena jika menyikat gigi dengan cara yang benar dapat mengurangi resikonya terjadi karies gigi. Adapun fakta dilapangan menunjukkan sebagian responden belum menyikat gigi dengan cara yang benar, sehingga menyebabkan terjadinya karies gigi. Untuk menurunkan angka kejadian karies gigi di puskesmas tersebut maka perlu mengadakan promosi kesehatan dengan menggunakan media promkes seperti lagu atau video yang menarik tentang simulasi cara menyikat gigi yang baik dan benar. Sehingga anak-anak dapat meniru gerakan yang ada di video secara tidak langsung mereka dapat menghafal dan merubah cara menyikat gigi yang sebelunnya kurang tepat atau salah.

\section{Kebiasaan makan dengan kejadian Karies gigi di Puskesmas Kemang Bogor Tahun 2019}

Berdasarkan hasil uji chi square, terdapat hubungan antara kebiasaan makan dengan kejadian karies gigi. Hubungan ini memiliki nilai $p$-value $=0,000$ berarti $<0,05$ sehingga berdasarkan uji statistic kedua variable tersebut berhubungan. Responden yang kebiasaan makannya baik berpeluang 12,917 kali untuk tidak terdapat karies gigi dibandingkan dengan responden yang kebiasaan makan kurang baik.

Berdasarkan Penelitian yang dilakukan oleh Mutiara Rina, 2016 tentang hubungan antara kebiasaan makan pada anak dengan kejadian karies gigi menyatakan bahwa adanya hubungan Kebiasaan makan dengan kejadian karies gigi. Kebiasaan makan dengan kejadian karies dapat dipengaruhi beberapa faktor seperti usia, gender, jenis makanan yang sering dikonsumsi, frekuensi makan serta frekuensi waktu makan memperlihatkan hubungan terjadinya karies. Menunjukkan diperoleh nilai $\mathrm{p}=0,000<0,05$ yang artinya bahwa ada hubungan yang signifikan antara kebiasaan makan dengan kejadian karies gigi. ${ }^{17}$ Penelitian ini sejalan dengan Made, 2016 yang menyatakan bahwa terdapat hubungan yang signifikan antara kebiasaan makan anak dengan kejadian karies. dengan hasil $p=0,001<0,05$ yang artinya variabel kebiasaan makan berhubungan dengan kejadian karies gigi. ${ }^{18}$

Menurut Khumaidi, 2007 kebiasaan makan adalah tingkah laku manusia atau kelompok manusia dalam memenuhi kebutuhannya akan makan yang meliputi sikap, kepercayaan dan pemilihan makanan. Upaya untuk membentuk kebiasaan makan yang baik hendaknya dilakukan sejak dini. Lingkungan yang sangat besar perannya dalam membentuk kebiasaan makan anak adalah keluarga. ${ }^{19}$

Menurut peneliti kebiasaan makan adalah seseorang memilih makanan apa yang dikonsumsi sebagai suatu kebutuhan atau kesukaan pada makanan tertentu yang bisa berdampak positif maupun negatif. Jika kebiasaan makan seseorang buruk dapat menjadi salah satu faktor penyebab karies gigi. Kebiasaan makan yang buruk seperti mengunyah menggunakan satu sisi, makan makanan yang manis dan lengket dapat menyababkan karies karena sisa makanan menempel di gigi yang tidak segera dibersihkan. Kebiasaan makan seseorang adalah kejadian yang berulang apabila tidak dirubah dapat memberikan dampak yang tidak baik bagi kesehatan gigi dan mulut. Orang tua dan guru dapat mengarahkan anak-anak untuk tidak jajan sembarangan atau makan-makanan manis yang dapat menyebabkan karies gigi.

\section{Kesimpulan}

Berdasarkan data di atas maka dapat disimpulkan bahwa faktor-faktor yang behubungan dengan kejadian karies yaitu frekuensi menyikat gigi, cara menyikat gigi dan kebiasaan makan. Dari fakta dilapangan didapatkan beberapa kejadian karies pada anak-anak, hal ini disebabkan karena orang tua tidak memperhatikan kebersihan gigi dan mulut anaknya. Seperti orang tua tidak membiasakan anak 
untuk menyikat gigi setelah makan pagi dan sebelum tidur, serta cara menyikat gigi yang salah juga menjadi faktor pendukung terjadinya karies.

Diharapkan dari hasil penelitian ini dapat dijadikan referensi yang dapat menambah pengetahuan mahasiswa tentang kesehatan gigi dan mulut di masyarakat. Institusi Pendidikan dapat memperbanyak literatur tentang kesehatan gigi dan mulut di masyarakat dan sebaiknya hasil penelitian ini dapat dijadikan informasi tambahan bagi pengembangan ilmu kesehatan.

\section{Konflik Kepentingan}

\section{Ucapan Terima Kasih}

\section{Pendanaan}

$-$

\section{References}

1. Mumpuni, dr Yekti dan Erlita Pratiwi. 45 Masalah dan Solusi Penyakit Gigi. Yogyakarta : Rapha Publishing; 2013

2. Fatimah. Tingkat Pengetahuan tentang Pemeliharaan Kesehatan Gigi Pada Siswa Kelas IV dan V di SD Negeri Widoro Kecamatan Danurejan Yogyakarta. Skripsi. Yogyakarta : Program Studi Pendidikan Guru Sekolah Dasar Penjas Jurusan Pendidikan Olahraga Fakultas Ilmu Keolahragaan Universitas Negeri Yogya; 2016

3. Putri M.H, dkk. Ilmu Pencegahan Penyakit Jaringan Keras dan Jaringan Pendukung Gigi. Jakarta: Penerbit Buku Kedokteran ECG; 2011

4. Kidd EAM dan Bechal SJ. Dasar-Dasar Karies-Penyakit dan Penanggulangan. Jakarta: Buku Kedokteran EGC. p. $2 ; 2012$

5. Sari S.A. Hubungan Kebiasaan Menggosok Gigi Dengan Timbulnya Karies Pada Anak Usia Sekolah Kelas 4-6 Di Sdn Ciputat 6 Tangerang Selatan. Tangerang Selatan: FKUIN; 2017

6. Kementrian Kesehatan Republik Indonesia. Riset Kesehatan Dasar 2013. Jakarta: Balai Penelitian dan Pengembangan Kesehatan; 2013

7. Kementrian Kesehatan Republik Indonesia. Laporan Nasional Riskesdas 2018. Jakarta: Kementerian Kesehatan RI; 2018

8. Kementrian Kesehatan Republik Indonesia. Riset Kesehatan Dasar 2012. Jakarta: Balai Penelitian dan Pengembangan Kesehatan; 2012

9. Puskesmas Kemang. Profil Puskesmas Kemang. Bogor: Puskesmas Kemang; 2018

10. Notoatmodjo S. Metode Penelitian Kesehatan. Jakarta: Rineka Cipta; 2012

11. Jumriani. Hubungan frekuensi menyikat gigi dengan kejadian karies pada siswa SD Inpres Kota Samarinda. Vol. 17 No. 2. Samarinda: Universitas Mulawarman ; 2018

12. Aprinta, dkk. Hubungan Frekunesi menyikat gigi dan Konsumsi makanan kariogenik dengan kejadian karies gigi molar pertama pada anak Sekolah Dasar usia 8-12 Tahun di Desa Pertima. Bali: Bali Dental Journal. Vol : 2 No 1 Hal : $1-8 ; 2018$

13. Anitasari S dan Rahayu NE. Hubungan Frekuensi Menyikat Gigidengan Tingkat Kebersihan Gigi. Yogyakarta: Maj. Ked. Gigi; 2010

14. Sari S.A. Hubungan Kebiasaan Menggosok Gigi Dengan Timbulnya Karies Pada Anak Usia Sekolah Kelas 4-6 Di Sdn Ciputat 6 Tangerang Selatan. Tangerang Selatan: FKUIN; 2017

15. Sunarti. Hubungan cara menyikat gigi dan jenis makanan yang dikonsumsi dengan kejadian karies gigi. Pekanbaru: Sekolah Tinggi Ilmu Kesehatan Tengku Maharatu ; 2018

16. Ramadhan. Serba-serbi Kesehatan Gigi dan Mulut. Jakarta: Bukune; 2010

17. Mutiara dkk. Hubungan kebiasaan makan dengan terjadinya karies gigi pada anak jurnal kedoteran gigi. vol 10 no 2. Jakarta: Universitas prof moestopo beragama; 2016

18. Made Budisuari. Hubungan Pola Makan dan Kebiasaan Menyikat Gigi dengan Kesehatan Gigi dan Mulut (Karies) di Indonesia. Bali: Buletin penelitian Sisten Kesehatan. Vol. 13 No. 1. 83-91; 2016

19. Khumaidi M. Gizi Masyarakat. Jakarta: BPK Gunung Mulya; 2017. 